\title{
LEARNING OF MARITIME VOCABULARY IN MARITIME STUDIES
}

\author{
Vilma Pranckevičiūtė \\ Lithuanian Maritime Academy
}

\begin{abstract}
Summary. English is "lingua franca" in the maritime industry. Due to the shift from "knowing the vocabulary" to "being able to use the English language in one's workplace", students are supposed not only to acquire maritime vocabulary but also be able to use it efficiently in the maritime context. In order to achieve this goal, students have to acquire large amounts of maritime vocabulary effectively and efficiently. The study analyses the strategies for vocabulary acquisition and how students use them in their studies. The results of the study show that lecturers acquaint students with basic maritime terminology. Students do not use all vocabulary learning strategies equally. The recommendations include encouraging the use of productive skills for vocabulary activation; more attention should be paid to the vocabulary learning strategies of memorizing and encoding, word formation and guessing from the context.
\end{abstract}

Keywords: maritime vocabulary, vocabulary learning strategies.

\section{Introduction}

English is "lingua franca" in the maritime industry and is standardized to the extent that every seafarer has to follow the proposed standard vocabulary for internal and external onboard communication. Despite the shift from "knowing the vocabulary" (i.e. standard marine communication vocabulary) to " being able to use the English language in one's workplace“, STCW (2011) requires navigators to be able to "use Standard Maritime Communication Phrases and use English in written and oral form" specifying the items to know in greater detail (ibid., p.105), while marine engineers should be able to "use engineering publications and to perform officer's duties" (ibid., p. 144, 172).

The attitude towards vocabulary acquisition is functional, i.e. students are supposed to not only acquire maritime vocabulary but also be able to use it efficiently in the maritime context.

The empirical observation of the students showed that the better students are at Maritime English, the better their skills of recording new vocabulary and putting it in the context are (e.g. writing words in the context, marking easily memorizable phrases, connecting the words into meaningful groups, using word formation for 
learning groups of similarly rooted words). The empirical observation has led to further study of the issue. It shows that the more successful students deal with vocabulary items unknown for them in a more efficient way than the others who do not note the items, do not refer to the dictionary so often and in general get lost having encountered a more sophisticated text.

The aim of the study is to investigate students' acquisition of Maritime English vocabulary in maritime studies. The research problem is that students acquire the maritime vocabulary not so efficiently and quickly.

The hypothesis was made that students do not use some vocabulary learning strategies and if so, they can be suggested using them more frequently or taught to use them thus increasing the efficiency of their efforts in vocabulary acquisition.

The objectives of the research include the review of scientific literature to define vocabulary acquisition strategies offered to be used for ESP that can be applied for the acquisition of Maritime English; and to survey the lecturers' contribution to teaching Maritime English terminology as well as vocabulary learning strategies used by the students of the Lithuanian Maritime Academy (LMA) and propose further directions for the vocabulary teaching and learning activities in this field.

The research methods used were the review of scientific literature, qualitative interviews with five lecturers of navigation and a quantitative survey of 83 students in maritime field (future navigators and marine engineers). All the respondents at the time of filling the survey questionnaire were taking any of the four compulsory courses of Maritime English. The questionnaire consisted of 25 statements on vocabulary learning strategies they use which had to be marked using a Likert scale whether they perform such activities or not. The questionnaire was based on the questionnaire for evaluating vocabulary learning strategies according to $\mathrm{Gu}$ (2018).

\section{Review of Literature}

Vocabulary is an essential part of the language that can promote or hinder communication. Its importance is signified by the publications issued by the International Maritime Organisation (IMO). The Standard Marine Communication Vocabulary (1977 and amended), replaced by the Standard Marine Communication Phrases (2001), constitutes the core maritime vocabulary to be learnt.

Another publication by IMO, the model course 3.17 Maritime English contains the methodological part providing many useful hints and advice on teaching and learning Maritime English; communicative approach, content-integrated language learning and content-learning integrating language are emphasized. However, vocabulary learning methods as a separate issue that could enhance the acquisition of maritime vocabulary are not discussed extensively as vocabulary is considered to be acquired through various teaching and learning activities per se. The notion here is that the acquisition of new vocabulary is a process that is taken for granted through the communicative tasks during classroom activities. To some extent, it is 
true due to the need for vocabulary contextualisation.

On the other hand, the vocabulary learning skill can be a valuable skill in a lifelong learning perspective. Vocabulary learning can be a well-organised activity performed consciously using vocabulary learning strategies (VLS). Gu (2018) defines the use of vocabulary learning strategies as strategic learning, meaning that a student understands the learning techniques he/she uses to achieve his/her aims: "Strategic learning is a deliberate, dynamic and iterative process for solving a learning problem, boosting the learning speed, or making the learning process efficient, effective, and pleasant".

Many factors can influence vocabulary acquisition, e.g. sharing with others (Nation, 2001), motivation and importance of the vocabulary to be learnt (Otten, 2003). According to Nation (2001), the process of remembering a new word entails at least three stages: noticing, retrieval and generative (creative) use. Noticing includes recognizing a word in a context, checking its meaning in the dictionary and/or finding out the meaning from the teacher, studying it deliberately and/or guessing its meaning from the context. The retrieval and generative stages have to include both receptive (listening and reading) as well as productive (writing and speaking) language skills.

The factors influencing the choice of vocabulary learning strategies depend on students' experience of foreign language learning at school as well as their experience during the ME course and possibly some other learning practices they may have had (e.g. private lessons, courses, summer schools, working and/or studying in a foreign country, etc.).

The best known taxonomy of vocabulary learning strategies is that of Scmidt's (1997) mentioned in numerous studies on vocabulary acquisition. The analysis of Schmidt's and related VLS taxonomies and types of strategies described by Letchumanan et al. (2018) are provided in Table 1.

Table 1. Summary of vocabulary learning strategies by Letchumanan, Muthusami, Govindasamy, Potchelvi et al. (2016).

\begin{tabular}{|c|c|}
\hline Category of strategy & Type of strategy \\
\hline \multirow{2}{*}{ Memory } & Creating mental images \\
& Applying images and sounds \\
& Reviewing \\
& Employing action \\
\hline \multirow{2}{*}{ Cognitive } & Practice \\
& Receiving and sending messages \\
& Analyzing and reasoning \\
& Making input and output \\
\hline \multirow{2}{*}{ Compensation } & Guessing intelligently \\
& Overcoming limitations \\
\hline
\end{tabular}




\begin{tabular}{|c|c|}
\hline Metacognitive & Entering learning \\
& Planning learning \\
& Evaluating learning \\
\hline \multirow{2}{*}{ Social } & Asking questions \\
& Cooperating \\
& Emphasizing \\
\hline Affective & Lowering anxiety \\
& Encouraging \\
\hline \multirow{2}{*}{ Determination } & Analyzing speech \\
& Contextual guessing \\
& Checking L1 cognate \\
& Consulting dictionary \\
\hline
\end{tabular}

According to $\mathrm{Gu}$ (2013), vocabulary learning strategy taxonomy contains cognitive and metacognitive parts. The metacognitive one constitutes beliefs about vocabulary learning and metacognitive regulation of vocabulary learning. The cognitive component includes initial handling, reinforcement, and activation strategies. Gu (2018) enhances metacognitive strategies by dividing them into selective attention and self-initiation categories of VLS. Another category added is inferring, i.e. guessing strategies, encoding, including visual and auditory ones, using word-structure and contextual encoding.

To sum up, the knowledge of Maritime English vocabulary is an indispensable part of the requirements set for modern seafarers to ensure effective communication in their workplaces.

Vocabulary learning should be a conscious process involving various vocabulary learning strategies in order to make the process effective.

\section{Analysis of the Research Results}

The quantitative interviews with five lecturers of navigation revealed that all of them provide professional terms of Maritime English during lectures of their subjects on ship handling, navigation techniques and rules, ship construction, etc. while explaining new theoretical concepts of professional subjects. Students get acquainted with the terms, but studies are conducted in Lithuanian and they do not use these terms actively (the new maritime terminology is not reproduced, i.e. productive language skills are not used). However, according to Nation (2001), it is important to use the words using both receptive and productive language skills in the retrieval and generative phases of vocabulary acquisition. It can be maintained that Maritime English courses are essential in the acquisition of maritime vocabulary, as the students learn just to recognize the words, and the activation of maritime vocabulary takes place during Maritime English classes.

For the quantitative part of the research, the survey sample consisted of 83 maritime students at the LMA. The questionnaire entailed the statements on different 
aspects of vocabulary learning strategies to be evaluated using a five-point Likert scale with the assigned meanings of "strongly agree", "agree", "neither agree nor disagree", "disagree" and "strongly disagree" with regard to their own vocabulary learning experience.

After the analysis of the students' survey results, it is seen that all VLS are used by the students but some are used rarely and only by some of the students.

The use of dictionary belongs to the determination techniques which is a common activity in professional English classes. 57\% of students admit using dictionaries frequently (see Figure 1). Compared to about $70 \%$ of them agreeing with the self-initiation statement on looking up words in dictionaries, this seems quite realistic that others might not need frequent look-up. This coincides with the results of other authors. I. Darginavičienè (2018) points out that "students prefer common techniques that have been familiar to them, i.e. to learn it from either reading or listening contexts and to look up the meanings of unknown items in the dictionary".

It might be that some of them just limit the use of dictionary with the direct translation of a word and they may need some more classroom activities showing how to look for differences and similarities of synonymous words (35\% of students admit doing so). Also, only $43.9 \%$ of students look up the usage examples which can be another area to work on during classes. It can be stated that the use of dictionary is frequent, but students could use it in more varied ways.

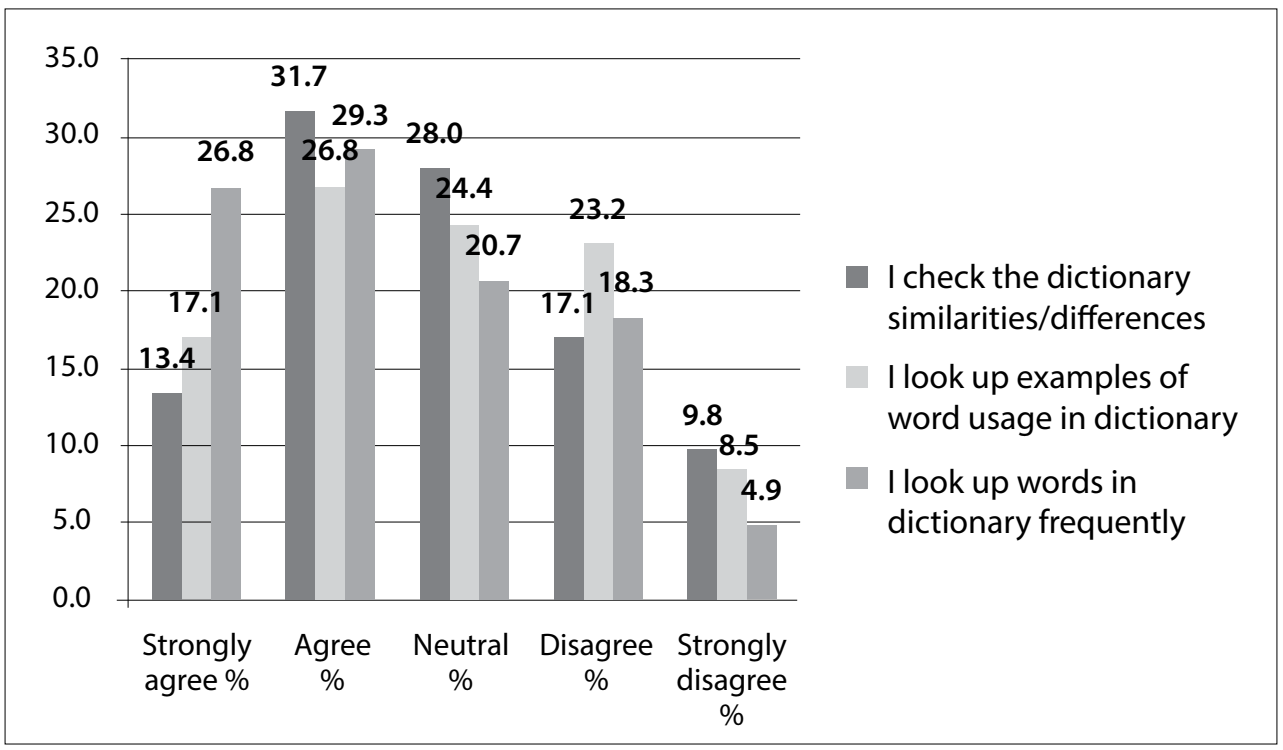

Figure 1. Dictionary use for vocabulary acquisition. Compilation by the author.

The memorization techniques, also called encoding techniques, are not used by all students. The survey results show that contextualization (remembering a word with a phrase) is the most frequently used vocabulary memorization technique. The 
least frequently used one is learning words by memorizing their pronunciation and spelling. Also, the repetition of already recorded vocabulary items is not popular (only $31.7 \%$ of students admit doing so). These results, as Mačianskienè (2012) points out, suggest acquainting the students with the set of memorization techniques and proposing them to select the ones that are the most suitable according to their learning style, context and situation. In addition, this suggestion can be proven by the research of Atay and Ozbulgan (2007). It investigated the use of vocabulary learning strategies by military ESP learners in Turkey. The experimental group of students was given a daily six-hour memory strategy instruction, while the control group received no special training. The post-test results on Air Traffic vocabulary acquisition showed that the experimental group showed a significant gain in professional terminology compared to the control group. Also, the experimental group showed the increase in the usage of vocabulary learning strategies.

Inferring meanings of unknown words is a fast and effective way of understanding professional texts. As Figure 2 shows, more than half of the students tend to infer meanings of the unknown words from the context but less than half of them tend to match the meanings with the text, being confident in their guesses. It is a positive as a compensation technique, but it can be quite a dangerous tendency which may lead to misinterpretation of important professional publications and, consequently, jeopardize ship's safety. It should be avoided by all means and the students should be taught to double-check before deciding on the exact meaning of the publications important for onboard decision-making.

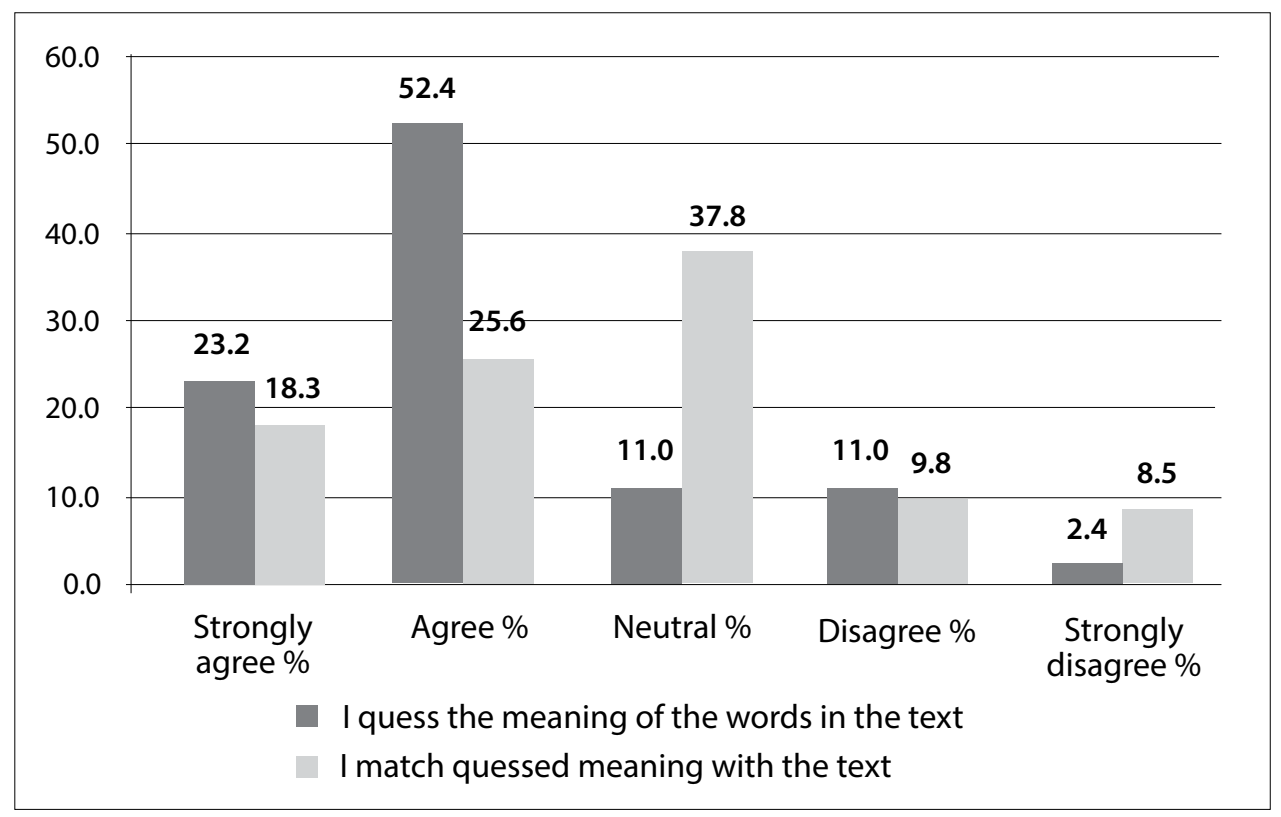

Figure 2. Inferring meanings. Compilation by the author. 
Talking about inferring of unknown word meanings, very few students neither used the word formation for guessing the meaning nor used this method for learning word families (only about $31 \%$ of students marked it as the vocabulary learning strategy used). This also has to be taken into consideration while teaching students vocabulary learning strategies.

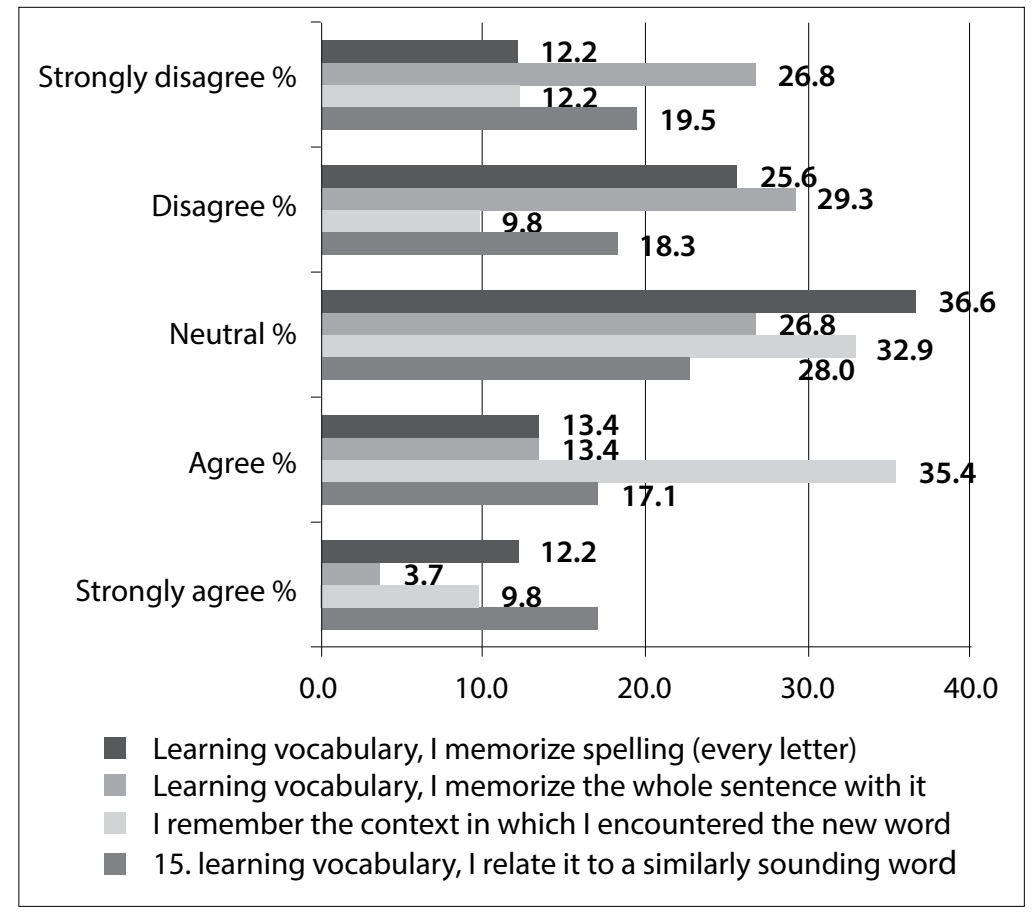

Figure 3. Vocabulary memorization techniques. Compilation by the author.

The evaluation of metacognitive and self-initiation strategies ("I read English texts that are additional to the course", "I read texts and look up new words in the dictionary") show students' high involvement and efforts: about $70 \%$ of them pointed out that they agree with the statement. As a proof, the value of reversed statement ("I am interested only in exam material") scored $66 \%$ of disagreements.

The question how to develop these strategies can arise naturally and the solutions could be sharing the experience in groups, deliberate grouping of the students with different VLS so that the weaker ones could acquire these skills, and designing some class activities that could improve dictionary use, contextualisation, visual, sound encoding, and other vocabulary learning strategies. 


\section{Conclusions}

The knowledge of maritime vocabulary is essential for seafarers in order to perform successfully as officers in their workplaces and cannot be overestimated.

The empirical observations of the Maritime English study process made it clear that students, even having sufficient language skills in general, have to cope with the lack of professional vocabulary in the field, while some require assistance in enhancing their vocabulary learning skills.

The recommendations for the enhancement of students' acquisition of Maritime English vocabulary as a second foreign language include encouraging the use of productive language skills. Vocabulary learning can be enhanced by boosting the use of less frequently used vocabulary learning strategies, such as memorization and encoding techniques, the use of word formation for vocabulary development, and paying more attention to the dangers of inaccurate guessing from the context.

\section{References}

1. Attay D., Ozbulgan C. (2007) Memory strategy instruction, contextual learning and ESL vocabulary recall. English for Specific Purposes, 26. p. 39-51.

2. Darginavičiene, I. (2018) Preferred Techniques for Learning ESP Lexis by Generation Z. Kultura i Edukacja, No. 2, pp. 37-50 DOI 10.15804/kie2018.02.02.

3. Gu, Y. (2013) Vocabulary Learning Strategies. In Chapelle, C. A. In The Encyclopedia of Applied Linguistics. Oxford, Blackwell.

4. Gu, P. Y. (2018) Validation of online questionnaire of vocabulary learning strategies for ESL students. Studies in Second Language Learning and Teaching. 10.13140/RG.2.2.16740.07047. [Accessed April 2019].

5. Mačianskienė, N. Užsienio kalbu mokymosi strategijos. At http://www. elibrary.lt/resursai/Leidiniai/Mokslotyros_institutas/Liekis/Ak_Edukologija/ Edukologija_17.pdf [Accessed June 2019].

6. Model Course 3.17 (2015) Maritime English, 2015 Edition. IMO, London.

7. Nation, I. S.P. (2001) Learning Vocabulary in Another Language. Cambridge: Cambridge University Press, available at http://dx.doi.org/10.1017/ CBO9781139524759 [Accessed June 2019].

8. Letchumanan, Muthusami, Govindasamy, Potchelvi (2016) An Overview of Preferred Vocabulary Learning Strategies by Learners.

9. Otten, M. (2003) Intercultural Learning and Diversity in Higher Education. https://journals.sagepub.com/doi/10.1177/1028315302250177.

10. STCW: Including 2010 Manilla Amendments. STCW Convention \& STCW Code. (2011) International Maritime Organisation, London.

11. Trenkner P., Cole C. (2012) The STCW Manila Amendments and Their Impact on Maritime English, Constanta Maritime University Annals 17. 


\title{
JŪRINIO ANGLŲ KALBOS ŽODYNO MOKYMASIS JŪRINIŲ STUDIJŲ METU
}

\author{
Vilma Pranckevičiūtè \\ Lietuvos aukštoji jūreivystès mokykla
}

\section{Santrauka}

Anglų kalba laivybos srityje yra „lingua franca“. Pasikeitus požiūriui, ne žodynas, o gebėjimas vartoti anglų kalbą savo darbo vietoje tampa svarbus. Iš studentų tikimasi, kad jie ne tik išmanys jūrinę terminiją, bet ir gebės ją vartoti savo profesinejje veikloje ir aplinkoje. Siekdami šio tikslo, studentai turi greitai išmokti labai daug jūrinių terminų. Darbe analizuojamos šio specialiojo žodyno mokymosi strategijos, kaip jas taiko desstytojai mokydami, o studentai mokydamiesi. Naudojami kokybinis dèstytojų ir kiekybinis studentų apklausos metodai. Tyrimo rezultatai rodo, kad dèstytojai supažindina studentus su pagrindine jūrine terminija, o studentai nevienodai taiko ịvairias žodyno mokymosi strategijas. Turètų būti skirta daugiau dèmesio tokioms žodyno mokymosi strategijoms kaip įsiminimo ir kodavimo technikos, žodžių daryba ir spejjimas iš konteksto. 


\section{AUTORIAUS LYDRAŠTIS}

Autoriaus vardas, pavardè: Vilma Pranckevičiūtè

Mokslo laipsnis ir vardas: magistré, lektore

Darbo vieta ir pareigos: Lietuvos aukštoji jūreivystès mokykla

Autoriaus mokslinių interesų sritys: andragogika, ELT, ESP, nuotolinis mokymas, jūrinè anglų kalba

Telefonas ir pašto adresas: +37068394931 , v.pranckeviciute@1ajm.lt.

\section{AUTHOR'S COVER LETTER}

Author's name and surname: Vilma Pranckevičiūtè

Academic degree and name: Master's degree

Workplace and position: Lithuanian Maritime Academy, Lecturer

Author's research interests: andragogy, ELT, ESP, distance education, Maritime English.

Telephone and e-mail address: +370 68394 931; v.pranckeviciute@lajm.lt 